This item was submitted to Loughborough's Research Repository by the author.

Items in Figshare are protected by copyright, with all rights reserved, unless otherwise indicated.

\title{
Western and Eastern building conservation philosophies: perspectives on permanence and impermanence
}

PLEASE CITE THE PUBLISHED VERSION

https://doi.org/10.1080/15583058.2018.1490827

\section{PUBLISHER}

(c) Taylor \& Francis

\section{VERSION}

AM (Accepted Manuscript)

\section{PUBLISHER STATEMENT}

This is an Accepted Manuscript of an article published by Taylor \& Francis in International Journal of Architectural Heritage on 13 August 2018, available online:

http://www.tandfonline.com/10.1080/15583058.2018.1490827.

\section{LICENCE}

CC BY-NC-ND 4.0

\section{REPOSITORY RECORD}

Forster, Alan M., Derek S. Thomson, Kendall Richards, Nick Pilcher, and Samantha Vettese. 2019. "Western and Eastern Building Conservation Philosophies: Perspectives on Permanence and Impermanence". figshare. https://hdl.handle.net/2134/34601. 


\title{
Western and Eastern Building Conservation Philosophies: Perspectives on Permanence and Impermanence
}

\author{
Alan Forster; School of Energy, Geoscience, Infrastructure \& Society, Heriot-Watt University, \\ Edinburgh, UK \\ Derek Thomson; School of Architecture, Building and Civil Engineering, Loughborough University, \\ Loughborough, UK \\ Kendall Richards; School of Computing, Edinburgh Napier University, Edinburgh, UK \\ Nick Pilcher; Business School, Edinburgh Napier University, Edinburgh, UK \\ Samantha Vettese; School of Arts and Creative Industries, Edinburgh Napier University, Edinburgh, \\ UK
}

\begin{abstract}
In this conceptual paper, we illuminate Western building conservation philosophy practice with insights into Eastern conservation philosophy and associated aesthetic understanding. We frame dialogue recognising individual and societal perspectives on treatments to buildings that attempt to attain 'permanence' or 'impermanence' in form, fabric, and artefact. Although not expressly sharing origins, Eastern and Western conservation philosophies practically yield commensurate or quasi approaches in intervention. These similarities have not been notably articulated before, and reveal meaningful insights for decision heuristics and guidance fundamental for repair scheme design and intervention. Western, pattern-based views relating to philosophical reasons around the impossibility of perfection, or 'correctness' in physical building form resonate with Eastern views supported by Kiku Kiwari. Moreover, universality in acceptance of Western Patina and Eastern Wabi-Sabi, and Eastern Kintsugi and Western legible fabric repair convey overt signals of philosophies beyond technical performance. Moreover, we find Western bias towards 'tangibility', and greater appreciation of 'intangibility' in Eastern approaches that are culturally enriching and go beyond mere retention of fabric and architectural form, linking building memory with territory. We suggest potential cross-fertilisation of thinking to create an environment of greater cultural understanding of the motives, thoughts and practices in East and West.
\end{abstract}

Key words: Building philosophies, Western and Eastern, Permanence and Impermanence, Conservative repair, Restoration, Fabric intervention 


\section{Introduction}

All buildings and fabric deteriorate (Alberti, 1966; Watt, 2009) in accordance with the universal law of entropy, and intervention is inevitable if serviceable condition is to be maintained (Forster, Carter, Banfill \& Kayan, 2011). That said, decisions regarding intervention methods and intent offer many possibilities (Muñoz Viñas, 2012), with approaches varying considerably. When conserving historic buildings, determining appropriate fabric interventions is situationally complex (Earl, 2006; Bell, 1997; Jokilehto, 2007; BS7913, 2013) and decisions often trigger emotive responses from lay persons and experts alike (Burman, 1995; Bell, 1997; Forster, 2010a, b \& c; Forster \& Douglas, 2010). These are arguably underpinned by different approaches to the idea of permanence, or the extent to which a building should be conserved in its original state. Conservation professionals require well-founded philosophy (or philosophies), and sufficiently informed guidance to navigate this complexity. Western ${ }^{1}$ building conservation philosophy has been characterised by two broad, often opposed schools of thought: Conservative Repair, and Restoration. Theoretically, the former is arguably grounded more in ideas of impermanence, and the latter more in ideas of permanence. In application however, they are often practically brought together and overlapped to achieve overarching architectural schemes. This requires conservation professionals to resolve complex issues and develop defensive strategies for their selected interventions. It is however, recognised that the overall suitability of the philosophical dialogue and technical fabric repair techniques are often assessed by an array of overseeing regulatory bodies that can halt a project's progress if they feel that they are unnecessarily insensitive and damaging. These bodies must themselves form philosophical value judgements and defend their reasoning for support or refute of proposed intervention.

Conservative Repair is a primary approach that seeks to do "as much as is necessary, (Brereton, 1995, p.7) yet "as little as possible" (Feilden, 2003, p.235), whereas 'Restoration' stimulates more extensive interventions. Each specific case must reconcile technical imperatives and relevant philosophical tenets from these Schools (Forster, et al., 2011; BS7913, 2013), despite patent difficulties and conflicts in doing so. Philosophical tenets should provide 'guiding lights' (Earl, 2006) of intervention, but their interpretation has been shown to vary depending upon the individual's professional education, perspectives and practice (Forster \& Douglas, 2010). The influence of Ruskin $(1851,1853)$, and more specifically Morris's creation of the SPAB Manifesto (1877) cannot be overemphasised, the latter evolving to become enshrined in international building conservation charters, most prominently: Athens (1931 (lamandi, 1997)), Venice (1964 (Jokilehto, 1998)), Burra (1981 (Logan, 2004)) and Appleton (1983 (ICOMOS, 1983)). Each Charter established the intentions of broad treatment approaches that contextualise specific conservation interventions within first-order Ethics and second-order Principles (c.f. Muñoz Viñas, 2012). Ethics are broader, overarching key concepts, and Principles are more specific criteria (Bell, 1997). Ethics address aspects such as authenticity (the non-distortion of evidence); integrity; avoidance of conjecture (the need for incontestable evidence); respect for age and historic patina and; respect for the

1 By 'Western' we principally refer to concepts and philosophies associated with the UK and Europe. 
contribution of all periods (Bell, 1997). Principles include: minimal (least) intervention; legibility (honesty and distinguishability); reversibility; materials and techniques (like for like materials); documentation (meticulous recording and documentation); and sustainability (Bell, 1997).

Ethics and Principles are understood to have certain contradictions and tensions such as that the Principle of using 'like for like materials' contradicts with the Principle of 'legibility' in so much as similar repair materials cannot be readily distinguished from original ones. They are therefore imperfect in implementation but do ensure that due consideration and analysis is undertaken before fabric intervention progresses. Nevertheless, the conservation charters both enshrine the ethics and principles and extend beyond to contextualise national specific issues that culturally and physically confront geographically unique situations. The overarching values and formulation of charters are, however, tempered in the pragmatic approach espoused by Powys that "each case ... must be considered on its own merits" $(1995$, p.3). Supporting this, holistic consideration of ethics and principles, akin to running a philosophical algorithm, is arguably undertaken in conscious and subconscious thought by conservation professionals. Hence, whilst somewhat vague in broad application, interventions are inherently technical, and are underpinned by philosophical reasoning. Therefore, much explicit and tacit professional experience is required to successfully navigate architectural change and fabric intervention. Attitudes to philosophical approaches are arguably educationally and culturally influenced, with pronounced intervention bias being an unintended consequence of professional conservation training (Forster \& Douglas, 2010) within national normative contexts of practice.

The dialogue required for spheres of conservation practice in effective resolution of complex specific cases would arguably benefit from greater universality and common intent to be established. Indeed, resolution of unique intervention complexity would logically be more defensible, by gaining insight into building conservation philosophies from East and West. Importantly, Eastern views on philosophies of repair have been contextualised in the Nara document on authenticity (1993). This seminal document is seen to encapsulate broader cultural issues considered of value in Eastern approaches to conservation. It emphasises the importance of 'intangible' cultural heritage that could be argued to have been somewhat neglected in Western philosophies that have traditionally focused on 'tangible' heritage. Of prime importance to the Nara document are "cultural heritage, its cultural context, and its evolution through time" (Nara, 1993). More specifically, the Nara document emphasises that "authenticity judgments" can be based on many sources, such as "form and design, materials and substance, use and function, traditions and techniques, location and setting, and spirit and feeling" (Nara, 1993). These concepts are not alien to Western thinking, and all are reflected in primary documents (Burra Charter, 1981 (Logan, 2004); cf. Avrami et al, 2000). It is, however, fair to assert that the more esoteric or subjective of these concepts, such as 'spirit' and 'feeling' have featured less in the pronounced analysis and application of fabric intervention in the West. Given the broad similarities in concepts, these should enable a global consensus, or at least understanding, to be achieved. Indeed, the Nara document arguably bridges the 
two worlds and is "commonly seen as recognising cultural differences between East and West as reflected in approaches to heritage conservation" (Akagawa, 2014, p.47).

As Akagawa noted, this was not only of concern to the Japanese, but, "rather it highlighted the fact that discussion about heritage had been predominantly carried out amongst European stakeholders and had not sufficiently accounted for global cultural diversity" (Akagawa, 2014, p.71). As Akagawa highlighted regarding the need for greater discussion amongst stakeholders worldwide: "this is and has been a fundamental issue that should have been addressed" (Akagawa, 2014, p.71). An increasingly embattled Eastern conservation community have had a certain element of recourse in so much as "the Japanese deserve credit for their courage in putting these issues before us to think of the validity of the universal principles" (Stovel, 1995, p.394, cited in Akagawa, 2014). Importantly, we note at the outset that many of the sources cited here have their own definitions of the terms used (cf. Richards \& Pilcher, 2014; 2018), and these may differ somewhat from Eastern definitions and understandings (Nara, 1993; Akagawa, 2014). For example, the Japanese language does not have a word that conveys the same meaning as authenticity (Akagawa, 2014) and it is more closely interpreted as being guided by 'genuineness' and 'reliability' (Ito, 1995).

Given the possible tensions outlined, we suggest that Eastern ${ }^{2}$ conservation philosophy is imbued with commensurate, quasi forms of Western approaches; and also with similar issues and tensions. Here, we argue that these ideas were not formed in isolation, and many pieces of Japanese art and pottery began to enter Britain from the seventeenth century onwards, providing "a major source of inspiration for many artists and designers in the period especially from 1850 to 1900" (V\&A 2017: no page). Even though a causal philosophical link cannot be overtly made, it can be hypothesised that key figures in Western thinking such as Ruskin were influenced by this 'opening-up' of Japan in the $19^{\text {th }}$ century. In addition, many Japanese architects (e.g. Okakura Tenshin and Maekawa Kunio) were educated in the West and buildings have been influenced by Western styles (Reynolds, 2001). Indeed, beyond architecture, the cultural influence of centuries of trade and exchange of knowledge, ideas and goods between East and West across the Silk Road (Niglio, 2012) cannot be discounted. To date, however, the relationship of Eastern and Western philosophies in historic building conservation have not been notably correlated. In this conceptual paper, we provide this correlation by exploring parallels, commonalities and tensions between and within Eastern and Western philosophies. We endeavour to determine what can be learnt by comparing philosophical and aesthetic concepts to provide a direction to the required further development of building conservation philosophy by reframing it on an international scale and attempting to refocus what can be, potentially, considered a Western building conservation philosophy bias. We do this as

2 By 'Eastern' we principally refer to concepts and philosophies associated with Japan even though many of them (e.g. Kintsugi) had non-local origins in the region (Gopnik, 2009; Paine \& Soper, 1960; Takagi, 2012) and that tensions within the region remain (e.g. Sino preference for symmetry being disharmonious to the traditional Japanese aesthetic (Keene, 1972)). 
follows. In Part One, we consider distinct conservation approaches common in Western contexts, while Part Two repeats this for Eastern contexts. Part Three then critically compares the two perspectives before Part 4 that consists of a focused discussion, drawing conclusions and suggestions for viewing such philosophies in a more universal manner.

\section{Part One: 'Western' Conservation Approaches}

Building conservation interventions are ideally underpinned by an understanding of applied philosophical reasoning to direct intent. Integral to this reasoning are conscious or possibly subconscious perspectives on permanence. Western ideals have been underpinned by Aristotelian notions of entelecheia that emphasise the work performed by an object at rest in its final (i.e. ultimate) form to retain that form (Sachs, 2005), yet also more Heraclitan (Guthrie, 1977) notions that celebrate the ideas of impermanence and the constant flow of time. In the following section, Western conservation philosophy has been subdivided into four approaches, with concepts of permanence and impermanence discussed throughout.

\section{Dominant Approach: Restoration and Conservative Repair}

Western conservation interventions typically adopt either 'Restoration' or 'Conservative Repair' approaches. BS7913 (1998, p.10) defines Restoration as the "Alteration of a building, part of a building or artefact which has decayed, been lost or damaged or is thought to have been inappropriately repaired or altered in the past, the objective of which is to make it conform again to its design or appearance at a previous date". Restoration is principally undertaken for idealistic aesthetic reasons, with many aspiring to restore buildings to a supposed aesthetic ideal for which documentary evidence is often scant or ignored, making conjecture unavoidable. Restoration thus adopts a firmly axiological perspective; an embodiment of the Western architectural aesthetic taken to its logical extreme, and in certain cases beyond, in a striving for permanence, and that consequently "to restore a building.... is to re-establish it in a state of completion which may never have existed at any given moment in the past" (Viollet le Duc, cited in Earl, 2006, p.54).

Restoration emerged from, and was influenced by, the late $18^{\text {th }}$ and $19^{\text {th }} \mathrm{C}$ 'Romantic Movement' (See De Botton, 2006), with fanciful extrapolation of architectural scheme designs applied to an array of historic buildings. Indeed, those partaking of the 'Grand European Tour' are known to have in many cases meticulously recorded and documented the ruins they visited (e.g. Ruskin (Brooks, 1989; De Botton, 2006); Viollet Le Duc (Jokilehto, 1998)), returning with broader aspirations to emulate ancient civilisations (especially Greek and Roman) permeating much $18^{\text {th }}$ and $19^{\text {th }}$ century thought (i.e. the Greek revival). Restorers came to view fabric interventions as opportunities to realise an intended, yet likely conjectured, building form. Conversely, Conservative Repairers considered it more honest to acknowledge that the passage of time entails 
impermanence, and that the realisation of initial, let alone ideal, building form and condition are inappropriate. As such, realisation would dilute the historic record and deceive.

The embryonic development of Conservative Repair is intertwined with the establishment of the Society for the Protection of Ancient Buildings in 1877, and is associated with John Ruskin (1819-1900) and, more directly, William Morris (1834-1896). Both opposed the Restoration of many culturally significant buildings happening at the time (Earl, 2006). Restoration was considered highly dishonest by Ruskin, who at the time wrote, "do not let us talk of restoration; the thing is a lie from beginning to end" (Ruskin, 1849, p.244). Ruskin also embraced the idea of impermanence and considered legibility of change and avoidance of conjecture (or the need for incontestable evidence) key, yet it was precisely these considerations that Restoration circumvented, aiming to create a permanent ideal and architectural aesthetic integrity.

Importantly, another element of conservation similarly guided by ideas of permanence in the West, is that of custodianship. Morris's assertion that "these buildings do not belong to us only... they are not... our property to do as we like with. We are only trustees for those that come after us" (1877, no page) underpins Western concepts of 'custodianship': a view arguably accelerated into Western statute following substantive building losses of the Victorian Restorations and the Second World War. The importance of a 'common inheritance' is omnipresent in the system, and custodianship attempts to generationally pass on a building's cultural, social and economic value. Intervention and facilitating change is supported, but this should not detract from the aspects of 'cultural significance' (Avrami et al, 2000) that identified the building as being worthy of conservation in the first place. Western perspectives on custodianship and property ownership therefore, potentially offer influence and 'temper' conservation interventions.

Today, the concepts underpinning 'Conservative Repair' permeate primary guidance on fabric intervention and, as BS7913 states, "no building or part of a building should be repaired before such repair is strictly necessary or unless there is a good reason" (1998, p.10). This is practically achieved by effective maintenance and the adoption of appropriate repair materials and techniques when intervention is inevitable. More recently, the values espoused in Conservative Repair approaches have been shown to positively support wider environmental fabric repair strategies that attempt to reduce expended carbon in intervention (Forster et al, 2011). The concept of minimal intervention, practically, and somewhat naturally, underpins 'low carbon strategies' deployed for historic buildings. These structures are often considered as being 'hard to treat' in terms of energy efficiency (Forster et al, 2011) and these approaches are reflective of an increasingly commonly asserted 'make do and mend', minimal intervention mantra. 
In implementation, a presumption that repairs will be legible (Cecchi \& Gasparoli, 2012; Forster \& Kayan, 2009) is also an important consideration with Conservative Repairers, who assert that conjecture is unavoidable in conservation but nevertheless seek to minimise it. They attempt to enact the values of honesty and distinguishability espoused in the SPAB manifesto (1877) so that interventions can be 'read' and 'interpreted' in the future. This minimises conjecture by promoting legibility via honest repair to safeguard authenticity, and arguably celebrates impermanence, given that any legibility inevitably exposes the aging and impermanence of a structure. Nevertheless, it should be noted that a key factor that makes such an approach possible is the fact that in the West, the climate is ostensibly more stable, with a relatively low frequency of natural disasters (principally lower seismic activity) meaning that buildings can attain greater longevity.

\section{Dominant Aesthetic: Permanence and the Classical 'Pattern Book'}

The conservation of historical classical and neo-classical aesthetic of Western architecture is typified by a design language that emphasises perfection and compliance with mathematical rules of proportion to achieve a philosophically 'good' (Honderich, 1995) building that, once created, is to be preserved in that ideal form. The rules of 'good' classical architecture were imbued in ancient remains but were transcribed for neo-classical buildings and prescribed in 'pattern books' dating back to, and typified by, Vitruvius' (1914) 'Ten Books On Architecture.'

In a search for a perfect architectural aesthetic, Vitruvius classified Greek and Roman architectural form to characterise features he considered ideal. Pre-empting axiological principles of value focused on realising objects in their ideal form (Hartman, 1967), Vitruvius prescribed floor plans and column layout proportions, and dimensional ratios for intercolumniation, column thickness and height, including the geometry of column entasis. In providing rules, his patterns distinguished between Roman and Greek classical orders for columns, capitals, friezes and entablatures (Vitruvius, 1914). Later, Alberti (1404-1472) re-evaluated Vitruvius's work, ostensibly as a 'practicing architect' to incorporate "the latest advances in mathematics, engineering and aesthetic theory" (Alberti, 1966: publishers note). He also dictated proportion and geometry of holistic building elements, and the ornament of columns, capitals and other enrichments (Alberti, 1966, p.141). Subsequently, Palladio (1508-1580) published his 'Four Books of Architecture' (Palladio, 1965), which became the 'touchstone' for those seeking to create 'authentic' neo-classical architectural schemes (Ackerman, 1966). Extensive adoption of Palladio's work led to codification of architectural form, which became the "renaissance scholar-architects" popularised pattern book for ordinary builders" (De Botton, 2006, p.28). Its adoption enacted the Western practice of pattern replication and the search for perfection through compliance. The resulting building forms became highly fashionable in the $19^{\text {th }}$ century, when prominent figures returned from their 'Grand European Tour' (De Botton, 2006) and sought to recreate their observations. In the $20^{\text {th }} \mathrm{C}$, various individuals contributed to the reproduction of classical architecture. Stratton (1932) explored classical form to graphically prescribe details and broader schemes (Stratton, 1932). Practical stone carvers consider Warland's (1984) 'Modern 
Practical Masonry' (first published in 1929) a source of patterns to direct restorative neo-classic reproduction. Today, although neo-classical pattern books per se are rarely followed, a 'new classical architecture' (Watkin, 2015 ) is sometimes constructed in postmodern schemes.

Yet, as models, pattern books will always be incomplete, raising the question of the degree of conjecture which can exist in conservation schemes that attempt to faithfully repair or recreate neo-classical structures. Whilst validity is created for pattern books or the utilisation of architectural detail drawings in neoclassical buildings, this level of detail is not available for forms such as vernacular architecture. It was on this basis that Ruskin vehemently opposed such conjectural interventions and the copying of ideals, and arguably rallied against such false attempts to seek permanence, noting that "direct and simple copying ... is palpably impossible. What copying can there be of surfaces that have been worn down half an inch? The whole finish of the work was in the half inch that is gone; if you attempt to restore that finish, you do it conjecturally" (Ruskin, 1849, p.xviii).

One prominent and highly relevant 'thought experiment' is known as the 'Ship of Theseus' or the 'Theseus paradox' (Scaltsas, 1980), first asserted by Plutarch in the $1^{\text {st }}$ Century AD and subject to analysis by contemporary philosophers (e.g. Hobbes, 1999). The experiment is contextualised around a timber ship in which each element and component is replaced successively over many years. No original material remains, but aesthetically the ship is visually identical to the original. To all intents and purposes, it is identical, but philosophical debate centres around whether the ship is the same or not (Plutarch, 1864) and thus, whether it is 'authentic'. In this case, restorers may argue that even though the ship is not 'original', it is authentic in that it is faithful to the original, although this will very much depend on how many of the timbers are replaced. If only a few are replaced, it is possible to argue it is the same, but if all of the planks are replaced, then any philosopher "cannot convincingly assert that the identity of the ship is unchanged" (Blair, 2006, p.48). Moreover, it is fairly clear that such a principle, although easy to apply in terms of replacing 'like for like' timbers in a structure at a chosen time, is untenable when it comes to the 'restoration' of an historic building for which replacements have to be hypothetically imagined, albeit often directed by historic records. From certain Western perspectives, authenticity requires the avoidance of conjecture, which in turn requires incontestable evidence. Yet, given the incompleteness of the historic record for almost all historic buildings, evidence in support of restoration is questionable. Today, although present technological advances such as digital reality capture (laser scanning and photogrammetry) and 3D printing will likely reduce conjecture to such a degree that the reproduced artefact will be a 'faithful' reproduction, it is nevertheless not original, and thus does not represent an ability to permanently create identical forms, particularly when aspects of legibility and respect for historic surfaces are considered. Although we consider Eastern perspectives in more detail later, we note here given its relevance, that the emphasis of the 'memory' of the building, has greater prevalence in the consciousness of Eastern cultural heritage actors when compared to the West. 


\section{Legibility of Honest Repair}

A legible and authentic building fabric is essential for determining cultural significance (BS7913, 2013). Central to legibility and key to Conservative Repair is that it makes repairs honest and distinguishable. Indeed, Conservative Repairers will often use alternative materials or construction techniques integrated into host substrates to ensure that repairs are legible. Although not identical, selected materials remain close to the originals, with compatibility (Rodrigues \& Grossi, 2007; Torney et al, 2014; Torney et al, 2012) being paramount. Fabric interventions of this type follow historically readable patterns and minimise conjecture about building form or purpose (Earl, 2006; Bell, 1997; Venice Charter Article 12, 1964 (Jokilehto, 1998)). Yet, tensions are undoubtedly created in attempts to simultaneously not debase architectural integrity as a whole, yet ensure that fabric repairs are legible. This poses various questions pertaining to the degree to which repairs should be 'readable', or perhaps even celebrated, and what type of audience the narrative of legibility is written for (i.e. the lay person or conservation expert). Such interventions, if insensitively undertaken, could create a patchwork effect and distract from the building's original aesthetic qualities (Earl, 2006; cf. Hill, 1995). Paradoxically, seamless interventions are widely supported for the repair of neo-classical architectural schemes, and this is reflected in BS7913 (1998), which emphasises that restorative interventions may be occasionally justified, particularly in Neoclassical buildings, as they can create aesthetic coherence. Materials and supporting craft skills play an integral role in this process and are symbiotic in attempts to attain architectural permanence. However, tensions exist in evaluating the distinguishability of intervention, thereby obviating deceit or aesthetic disfigurement. Hill (1995) resolves such tensions by classifying buildings as 'living' or 'dead.' Living buildings are those that still fulfil their original purpose and are repaired and maintained in the same way, whereas dead buildings are no longer used and are supported by Conservative Repair. However, this distinction alone cannot safeguard Legibility when conserving living buildings, as Hill's distinction could lead to schemes involving conjecture that are "potentially deceptive; a modern counterfeit replaces the genuine qualities of age" (Bell, 1997, p.29). These factors are critical for accurate interpretation and analysis of existing historic building fabric and architectural form, and poorly considered intervention debases the historic record.

Legibility grounds Honest Repair securely in the concept of authenticity, and of the authenticity of impermanence. This is in contrast to the Restorer's attempt to achieve an idealised original form, permanent in aim, but lacking authenticity in outcome. Legible and Honest Repair adopts the premise that the original form cannot be realised and, as Bell importantly notes, "all original fabric is authentic but not all authentic fabric is original" (1997, p.28). Moreover, attempting to attain a unified aesthetic whole can be detrimental to the 'cultural significance' of a structure $(B S 7913,2013)$ and indeed, it must be recognised that 'respect for the contribution of all periods' is considered a first order 'ethical' consideration (Bell, 1997) in Western conservation practice. 


\section{Respect for Historic and Aged Surfaces}

As buildings age, their surfaces acquire patina as an emergent quality marking their impermanence. Patina was integral to Ruskin's weltanschauung. He asserted patina was precious, creating a metaphorical 'golden stain of time'. As the accumulation of age cannot be accelerated (Ruskin 1851), patina is significant to any historic building through contributing to its character ('mellowness'). Ruskin accommodates this, asserting that "Imperfection is in some sort of way essential to all that we know in life. It is the sign of life in a mortal body, that is to say a state of progress and change... and in all things that live there are certain irregularities and deficiencies which are not only signs of life, but sources of beauty" (1851, p.171). Indeed, patina is unavoidably associated with impermanence, advancing degradation and the aging of surfaces (i.e. crusts in stone, and corrosion in metals), and may thus require intervention via the removal of certain accretions or the replacement of materials (i.e. sheet metalwork) at the end of their functional life. Unnecessary removal of patina for urban regeneration or to attain a unified architectural aesthetic whole is, however, undesirable. As Ruskin commented on such restoration in the 19th century: "The whole finish of the work was in the half inch that is gone; if you attempt to restore that finish, you do it conjecturally" (Ruskin, 1849, p.xviii). Removing patina via cleaning can have significant implications for material surfaces, adversely and irreversibly changing buildings through the treatment process, and corrupting fabric authenticity in buildings (Milligan in Webster, 1992; Simpson in Webster, 1992). There is a general presumption against its removal.

\section{Part Two: "Eastern" Conservation Approaches}

Having characterised approaches prominent in Western conservation discourse, Eastern conservation is now reviewed. These approaches are enacted within a distinctly Eastern (read: Japanese) aesthetic ${ }^{3}$ that although in many ways can be considered uniquely Eastern, is similarly underpinned by ideas of impermanence and permanence. Notably, Eastern conservation can be examined by considering approximately the same four approaches as prominent in the West.

\section{Dominant Approach: Kiku and Kiwari}

Kiku and Kiwari support traditional skills for the continuous maintenance and repair of wooden architecture. They are processes (Yamato, 2006) for using wood when constructing or reconstructing traditional buildings: "when parts of a building need to be replaced, carpenters are able to reproduce the missing original components using the kiku and kiwari methods" (Park, 2013, p.500). Jokilehto (2007) believes these unique to Japan, although they developed from similar techniques arriving from China in the $6^{\text {th }}$ century (Kuroishi, 2015; Paine \& Soper,

3 Notably, Japan considered aesthetics to be so intrinsically bound up in the meaning of artefacts that the abstract term 'Bigaku' (美学) was not coined until 1883 when it became necessary so that Cultural Properties could be debated with Westerners, who relied on Hegel's ästhetik lens; the science of the fine arts (Richie, 2007). 
1960) and are considered sufficiently valuable to receive government funding and protection (Yamato, 2006; Park, 2013).

Kiwari (木割) was established in the Momoyama period to provide consistency to roof designs by defining patterns of intercolumniation dimensions, column sizes, distances between roof rafters; and by coordinating all other roofing elements as modules within these dimensions (Kuroishi, 2015). These patterns led to the formalised, yet elaborate, system of Japanese carpentry joints used by apprentice carpenters to demonstrate their craft. In the following Edo period, Kiwari became more prescriptive and focused on numerical ratios, prescribing possible building forms (ibid.). It became "a system of modular proportioning of the overall structure, the spacing of the columns, and the proportions of each member" (Ito, 2003, p.6). Kiku (規矩) provides standard templates for the sophisticated geometrical system that combines sloped roof members with the up-turned eaves at roof corners "by working out calculations of the depth of the eave, the degree of the curve, and the shape of the cut surface of each member" (Yamato, 2006, p.6). It results in full-sized templates for the cutting of timber (JAANUS, n.d.). Together, Kiku and Kiwari standardised the prefabrication of components as a "common practice ... as a result of modular proportioning geometric calculations" (Park, 2013, p.500). This meant that "architectural construction became a comprehensive, unified, rationally organized industry, controlling everything down to the sizes of wooden members available in the lumber market" (Yamato, 2006, p.6). This was intended to prevent deviation from original built form, establishing a perceived faithful reproduction and avoiding conjecture about the patterns they enabled. In a specifically Japanese understanding of replacing timber, this would often be undertaken for aesthetic reasons to ensure the building was not only preserved but also neat (Ito, 1995). Here, the use of Kiku and Kiwari is contextualised within an approach to conservation which is uniquely Japanese and considers and takes account of "authenticity in ways which accord full respect to the social and cultural values of all societies" (Nara, 1993). To some extent, this can be seen in examples such as the Ise Grand Shrine, rebuilt every twenty years in two adjacent sites, although such approaches to replacing timber are often contextualised within religious norms specific to each temple (Akagawa, 2014) rather than emphasising impermanence. Moreover, the reconstruction of the entire building, as happens with the Ise shrine, is uncommon (Akagawa, 2014). In addition, the major works required for Horyuji temple have involved much replacement of major and minor amounts of timber, "considered to be the necessary natural response at various points in the life of a wooden structure" (Akagawa, 2014, p.77), particularly given the nature of the climate in Japan (Paine \& Soper, 1960). It must be emphasised that the replacement of fabric, whether legible or not, is inevitable in both Western and Eastern architecture, but the seismic hostility associated with Japan creates an environment for higher levels of intervention with greater frequency. Indeed, the scale of loss can be contextualised by the Great Kanto earthquake of 1923, which destroyed 95 percent of the town of Yokohama (Kuroda, 2016).

Interventions to buildings are often designed to develop community cohesion through "machizukuri (town making) and furusato (hometown) used by the Japanese government in utilizing heritage landscape to influence 
people's sense of identity" (Akagawa, 2014, p.47). These approaches can be argued to be culturally enriching and go beyond the mere retention of fabric and architectural form, and one "that links to the memory and identity of the territory to which they belong" (Niglio, 2014, p.1), with buildings often being personified, as in the case of Himeji Castle (Utaka, 2013). In addition, they help retain traditional craft skills essential for the repair of historic buildings, particularly given Japan's hostile climate and geological instability (Jokilehto, 2007). Notably, as Richie indicates $(2007$, p.38), in these attitudes to rebuilding, "permanence through materials (granite, marble, the Pyramids, the Parthenon) is seldom attempted. Rather, the claims of immortality are honoured in another way." Thus, it is the process of creation that is valued; not the resulting artefact, and it is this that is considered 'authentic' in Kiku and Kiwari. Indeed, increasing prominence is being given by the UNESCO convention on Intangible Cultural Heritage (ICH) asserts that it is important that, "rather than focusing on preserving craft objects, safeguarding attempts should instead concentrate on encouraging artisans to continue to produce craft and to pass their skills and knowledge onto others, particularly within their own communities" (UNESCO, 2017, no page). Japan has also played a key role in UNESCO, with Matsuura Koichiro being the head of UNESCO, and with Japan playing a key role in cultural heritage worldwide (Akagawa, 2014). This is important as traditional Japanese building conservation could be argued to have become embattled, finding itself having to defend its actions to a Western view of intervention appropriateness. Indeed, an international conference attendee (cited in Akagawa, 2014, p.74) felt Western views were being imposed on the Japanese: "The Japanese heritage practitioners were [verbally] bullied as if our practice was not acceptable and [therefore] wrong" (mentioned at a seminar held in Tokyo in August 2009). This caused confusion amongst Japanese practitioners, who found it difficult to apply concepts of Western authenticity to Japanese conservation. In the words of Ito Nobuo (2002, p.16): "We Asian experts in charge of conservation works were much embarrassed with this method of minimum intervention. We thought we had other ways of conservation and should keep the essence of these ways even in future. We were much troubled". Indeed, this argument reflected a Western bias and a failure to consider the cultural issues at play in Japan and clearly strengthens the requirement for greater international dialogue and understanding of values and intervention.

Clearly, Kiku Kiwari, as a process, has significant consequences for what is being conserved: building and art is, and represents, one approach in philosophy to celebrating impermanence. Other very different ways in which such impermanence is celebrated and approached in Eastern philosophy is through the notion of Wabi Sabi, and the use of Kintsugi, or golden repair.

\section{Dominant Aesthetic: Impermanence}

Eastern approaches to conservation are enacted within a culturally-ingrained aesthetic that embodies both appreciations of visual beauty and also intents about how artefacts should reflect cultural ideologies. Notably, the conservation of historic buildings occurs within a broad cultural aesthetic that finds beauty and meaning in 
impermanence, repair and the passing of time. These aesthetic sensibilities are grounded in what Keene (1972, p.13) terms "irregularity, simplicity, and perishability." Perishability is "based on the Buddhist concept of mujō, a term usually translated as 'impermanence': nothing is stable, and our only refuge lies in accepting, even celebrating this" (Richie, 2007, p.18). As Keene notes, the Japanese traditionally "expressed their preference for varieties of beauty which most conspicuously betrayed their impermanence" (1972, p.24). This valuing of perishability and impermanence has considerable impact on building conservation and the extent and nature of conservation interventions to Eastern Cultural Properties. Intervention appropriateness can be understood by considering three dimensions of Eastern aesthetics: Kiku and Kiwari (considered above), Kintsugi, and Wabi Sabi.

\section{Legibility of Kintsugi}

Kintsugi is thought to originate in the development of the Japanese tea ceremony in the late $16^{\text {th }}$ and early $17^{\text {th }}$ centuries (Keulemans, 2016). Kintsugi (金継ぎ) (Japanese: golden joinery) or Kintsukuroi (金繥い) (Japanese: golden repair) are prominent in Japanese artefacts; specifically, ceramic conservation and manufacture. Kintsugi involves repair using urushi (Weintraub, Walters \& Tsuijimoto, 1979): in English, lacquer (Kwan, 2012) whereas Kintsukuroi uses gold enamel (Larkosh, 2014). Although materials differ, the visual result is identical. With Kintsugi, broken ceramic pottery artefacts are mended by covering cracks with black lacquer, then a layer of red lacquer and finally a layer of gold through a dusting of gold powder or the use of gold leaf. In this way, "each repaired vase, cup or bowl is shot through with gold veins that map and exalt a moment of impact" (Starling, 2008, p.123).

Kintsugi and Kintsukuroi both consider breakage and repair integral to an object rather than something to disguise as "Japanese value the marks on objects left by aging. They believe... everything has a story... we should work hard to preserve... instead of removing... a 'good' piece should be functional and at the same time all the marks are kept" (Kwan, 2012, p.7). Kintsugi represents "above all a celebration of the irreversible nature of time and of entropy" (Starling, 2008, p.123). For objects repaired with Kintsukuroi, "many consider the resulting repaired object even more beautiful in its reconstituted brokenness than when it was intact" (Larkosh, 2014, p.74). Keene notes, "The visible presence of perishability in the cracked tea bowl carefully mended in gold has been appreciated not because it makes the object an indisputable antique, but because without the possibility of aging with time there could be no real beauty" (1972, p.24). Indeed, sometimes artefacts are "purposefully broken" (Keulemans, 2016, p.18) for Kintsugi, and perceived to be of higher value when repaired. Kintsugi's "urushi is used to repair lacquer, wooden sculpture, architecture and ceramics" (Weintraub et al., 1979, p.xi). Kintsugi is thus honest, and repairs made with Kintsugi are not only passively legible, but actively so. The selected materials used in the repair leave no possibility for conjecture about artefact history. Integrity is not in any way 
debased by celebrating imperfections. Thus, Kintsugi ${ }^{4}$ has an extremely high level of authenticity in its clear celebration that the original cannot be retained. Imperfections resulting from honest repair are made fully legible to appreciate impermanence and perishability. Such appreciation is also evident in other Eastern philosophies.

\section{Respect for Historic and Aged Surfaces}

Wabi Sabi (侘 寂) originates in Chinese Taoist philosophies that emphasise and celebrate the continuous flow of the world and its impermanence (Juniper, 2011). Along with Kintsugi, Wabi Sabi acknowledges time and its effect on objects. Yet, whereas Kintsugi is a process, Wabi Sabi is a concept; a state of mind. Wabi's direct translation is "poverty" but in aesthetics it relates more to aging and the marks or effect of time (Kwan, 2012). In modern times the various meanings of Sabi have been largely maintained. One of these indicates the patina of 'rust'; of age. When the Kinkakuji (Gold Pavilion) was rebuilt after its destruction by fire in the 1950s, it was dazzling in its splendour but a guest was overhead to say "let's wait ten years, till it's gotten some sabi" (Richie, 2007, p.46).

Wabi Sabi celebrates "impermanence, humility, asymmetry, and imperfection" (Juniper, 2011, p.2; cf. Koren, 1994) and like Kintsugi, it treasures the beauty of impermanence and encapsulates a philosophical justification and celebration of visible repair. Just as Kintsugi has wider application to areas other than ceramics, and wooden sculpture, the concept of Wabi Sabi also has wide application in a variety of fields, including computing (Holman \& Vertegaal, 2008), aesthetics and learning (Treviranus, 2010), and architecture (Suebsuk and Nakagawa, n.d.). Indeed, it is possible to see the retention of older parts of buildings as integral to a Japanese approach to functionality and purpose of the structures involved, such as in the development of Yokohama (Kuroda, 2016), or in the development of Tokyo University campus and Ueno Park (Nishimura, 2008). Here there is almost a 'plasticity of planning' that allows future directed intentions to retain 'reasonable stability' through retention of older parts and their integration with new in a concept of plasticity (Makowski, 2016). Furthermore, Wabi Sabi is integral to the aesthetic understanding and appreciation of the tea ceremony (Okakura, 1906) as a reminder of the humbling of the participants and the artefacts to the process of the ceremony.

As a philosophical concept, the ennui of Wabi Sabi underpins Kintsugi, and again, the imperfection and passage of time are openly acknowledged. Rather than attempting to return an object to an initial state, it is aesthetically transformed into something aged and marked by the passage of time. Changing from its original form is considered a source of beauty. In this context, Richie $(2007, \mathrm{p} .38)$ notes "Cherry blossoms are to be preferred

4 We recognise that Kintsugi and Kintsukuroi differ in their use of materials, but given the similar appearance and aesthetic meaning, for ease of readability we hereafter use the term Kintsugi. 
not when they are at their fullest but afterwards, when the air is thick with their falling petals and with the unavoidable reminder that they too have had their day and must rightly perish."

Part Three: A Comparative Discursive Analysis of Western and Eastern Philosophical Stances and Cultural Notions

Despite a number of contextual factors underpinned by climate (Paine \& Soper, 1960), natural disasters (Kuroda, 2016), and interpretations of language (Akagawa, 2014), which we would both note are omnipresent and also desirable (Nara, 1993, Niglio, 2014), we argue that Western and Eastern approaches to conservation show striking parallels in underlying key philosophies, and ideas regarding permanence. As the previous sections have outlined, parallels and commonalities exist between West and East in perception and approaches to certain aspects of building conservation and repair. Nevertheless, tensions are noted, and in certain cases paradoxes exist in these philosophical treatments to architecture and artefacts and their ideas of permanence. It is these parallels, commonalities and tensions that we discuss here.

\section{Dominant Approaches and Aesthetics}

The Western pattern book approach to the 'restoration' of neo classical buildings seeks permanence through attempts to limit conjecture, and clearly has direct parallels with the Eastern ideas of Kiku and Kiwari for timber shrine architecture. Both are documentation processes used to direct operatives and designers in faithful reproduction of architectural assemblages, through design and appearance (pattern book) or through approach and technique (Kiku and Kiwari). Yet, neither approach is able to circumvent the first order need for legible intervention in accordance with the 'ship of Theseus' paradox. Such replacement of timbers is often seen as not only necessary, but also beneficial in a Japanese context $($ Ito, 2002) particularly given the nature of the climate (Paine \& Soper, 1960). Questions remain regarding the degree to which conjecture is present both in Western schemes that attempt to faithfully repair or recreate classical structures, and also in Eastern schemes that rely on different individuals reproducing structures over time. Copying, whether it is from old styles to create fully new buildings, or whether it is to restore old buildings by adding new material, inevitably involves conjecture, yet this was something that advocates of honest repair in the West (contra Nara, 1993) have continually protested against.

In addition, in the West, the idea of Pattern books is supported by a philosophy aiming to create permanence and continuity; in the East, Kiku and Kiwari are strengthened by a more subtle philosophy that recognises that continuity of a tangible building is achieved through celebrating the permanence of the intangible process of replacement. Western views of beauty and meaning that emphasise the result of the creative process over the process itself, and carry deep-rooted assumptions that artefacts must be preserved in their form when discovered and decreed to be meaningful. In stark contrast, Eastern views of form emphasise creation and 
change to achieve preservation. Thus, there remains a focus and desire for permanence and tradition in these Eastern approaches in their use of materials and techniques.

In the context of these aesthetics and principles, and of ideas of permanence, we would argue that a key factor today is that advancing recording technologies offer the potential to ostensibly obviate the conjectural aspect of the documentation process. Digital reality capture (especially laser scanning and photogrammetry) has never been associated with greater levels of point cloud density and completeness of data and therefore would logically support re-creation based on the concept of 'digital pattern books' or in current parlance, scan to HBIM and Scan to 3D print applications (Jiang et al, 2016). This has become more contentious given recent advances in 3D printing technologies that potentially, materially and textually facilitate the recreation of components that, when cumulatively combined, may recreate holistic schemes (Guardian, 2016). Nevertheless, whilst such technology enables a greater likeness, it does not resolve the 'Ship of Theseus' thought experiment. Importantly, we are at a stage in history were it may be technically possible to rapidly recreate the weathered surfaces and textures noted by Ruskin, but we have potentially entered what could worryingly be termed a 'golden period of deceit'.

\section{Legibility}

Through the practice of Kintsugi, the Japanese openly celebrate entropy and decay, and thus impermanence, via legibility in repair, as imperfections are celebrated with the tangible and strikingly visible gold that is used to join together broken pieces of pottery which, although not comparable in scale, is materially analogous to Western legible repairs in historic structures. Logically, Kintsugi has direct parallels with Ruskin's celebration of decay, and architectural fabric intervention contextualised around honesty and legibility. Both Kintsugi and honest repair send messages or overt signals of philosophies beyond the technical performance of the mended artefact or architecture. Here, it is clear that common cultural perspectives relate to the acceptability of the visibility of mending finds outlets in both cultures. The importance of what makes a good piece of Kintsugi transcends the material fabric insomuch as it "should be functional and at the same time all the marks are kept" (Kwan, 2012, p.7). These dual technical and aesthetic features would undoubtedly resonate with those who support honest repair and legibility and beauty in decay. Surprisingly however, the Japanese appear not to readily upscale this philosophical approach in application to buildings, although there appear to be moves in Japan to more readily accept honest repair in architecture. Recently, the Japanese Association for the Conservation of Architectural Monuments, tasked with conserving those historical buildings and monuments considered 'Cultural Properties' by Japan's Agency for Cultural Affairs (文化庁), has notionally adopted a similar honest repair stance when selecting intervention 'strategies'. Indeed, it is also recognised (Larsen, 1994) that approaches in the East are influenced by Article 11 of the Venice Charter that asserts "The valid contributions of all periods to the building of a monument must be respected, since unity of style is not the aim of a restoration." (Venice 1964 (Jokilehto,1998)). It would appear logical that the concept of beauty in decay and visible mending 
is culturally engrained in Japan supporting notions of the acceptability of these forms of fabric intervention to gain traction. Yet, any interpretations of motivation here need also to consider the contextual importance of functionality of buildings in Japan to townmaking (machizukuri) and hometowns (furusato) (Akagawa, 2014).

Within a UK context, a clear parallel is the recognition of impermanence through the application of honest repair strategies that overtly express the presence of the legibility of intervention to buildings and arguably permeate primary conservation guidance (BS7913, 2013). Yet, honest repair can be aesthetically contentious and clearly objectionable to many. It is argued that it debases the fundamental integrity of the architecture it purports to meaningfully support. Those conservation practitioners who support and adopt honest repair argue it is important in conveying the story of fabric and building change. In parallels with Kintsugi, such interventions are argued to contribute to the beauty if not the integrity of the structure.

Investigating the specific application of these philosophies in practice in the West and East, it is clear that in Japan, Kintsugi does not appear to upscale to buildings and larger structures, although for reasons of functionality and public use (Nishimura, 2008) Japanese approaches readily retain old parts or sections of buildings and landscapes alongside new. Conversely, in the West, honest repair does not appear to downscale to smaller items, and any damage is seen as debasing the value and integrity of the object. There thus appears to be a presence of conflicting and dissonant values.

\section{Respect for Historic and Aged Surfaces}

Western philosophies and ideas related to the importance of patina (to Ruskin the 'golden stain of time') find direct parallels in the Eastern philosophy of Wabi Sabi, in the celebration of aging and of imperfection. Both concepts support shared understanding and value placed in aged surfaces but overtly convey an expectation of this being present in historic fabric, and thus celebrate impermanence. Wabi Sabi and the 'golden stain of time' move beyond the first order requirement of an old building manifestly looking old, instilling a heightened sense of aesthetic beauty in imperfection. In Wabi Sabi, imperfections in artefacts that emerge over time, either natural or accidental, are celebrated and judged to be of high aesthetic beauty for their celebration of aging and impermanence. A key parallel exists with the Western celebration and value of patina, the 'golden stain of time'. Here, both in the West, with patina, and in the East, with the progress of decay, there is an active celebration of the passage of time, and an active appreciation of the beauty of aging and of impermanence.

The Western idea of aging over time and patina does apply at both an architectural level and also at the level of artefacts. It is also arguable that the specific length of time involved in such philosophies and processes is key. Indeed, the vast majority of western architectural listings are associated with old buildings (as opposed to modern structures that have been designated shortly after completion-i.e. Lloyd's Building, London, Circa 1986) 
and therefore they are expected to have a commensurate level of patina relative to age. That said, not all evaluators in the West appreciate patina and many simply see it as unwanted 'grime'. It could be argued that those taking this view most highly value permanence of the ideal notion of architectural original form.

\section{Discussion and Conclusions}

This paper has outlined a number of key Western and Eastern philosophical approaches to building conservation and repair. It has argued that ideas and approaches to permanence and impermanence, despite a number of complexities and subtleties, show a striking degree of similarity. This is practically reflected in many aspects of underpinning philosophies and primary tenets. Indeed, in many cases they appear almost as proxies for each other. As the above consideration shows, culturally, a significant proportion of Western and Eastern conservation practice recognises the importance of the overt identification of permanence in architectural form. The mechanisms by which they achieve this, or the degree to which strategies are implemented, vary depending upon the philosophical orientation, professional education of relevant actors and, occasionally, upon financial constraints. Among these actors, individuals, companies, governmental bodies and legislative frameworks can support conservation practice and enact philosophical norms through organisational ethos, interpretation of conservation charters, and planning policy.

In terms of approaches to reading building fabric interventions, there are striking similarities between Kintsugi's celebration of honest repair and Western Conservative Repair approaches to fabric repair that seek overt legibility. Nevertheless, although honest repair is an approach favoured by many conservation professionals in the West, it is arguably a UK-centric subset of Pan European approaches. This UK-centric subset does not universally find outlets in the West, and support for honest repair is largely derived from exponents of a 'Ruskinian' tradition that aspire to avoid conjecture, and, ultimately, deceit. Ruskin's philosophical orientation is viewed through a lens of 'truth' requiring legibility in application. This world view can be criticised for being too narrowly focused and may not effectively reflect the kaleidoscopic reality of contemporary conservation practice. In defence of Ruskin, the seamless, illegible repair of historic buildings causes irreconcilable difficulties in the interpretation of architectural change and therefore the deciphering of history. Indeed, detractors of legibility or overt honest repair interventions highlight the debasement of the integrity of the repaired architecture. 'Battle lines' have been drawn between 'conservative repairers' and 'restorers' for almost a century and critics (e.g. Hill, 1995) argue that honest repair simply advertises the philosophy of those undertaking the intervention in artefact or architecture. Yet, this argument fundamentally fails to understand the motives for intervention. Indeed, the overt legibility manifest in Kintsugi helps create a world view and potentially a broader acceptance of the aims and intent of honest repair intervention. The importance of deriving better understanding the motives of the Japanese in their creation of Kintsugi pieces underlies their perception of beauty in decay and change processes that are essential for the interpretation of their treatments. 
Kintsugi arguably helps absolve conservative repairers and supports honest repair strategies, giving it a greater universality and weight to the narrative of the story of architectural fabric change.

Another noticeable similarity in the celebration of the idea of impermanence is the appreciation of aging in surfaces in the West and, in the East, of objects. The manifest appreciation and valuing of patina, or, as Ruskin poetically described it, 'the golden stain of time', appears well understood and is generally supported with the exception of selected urban regeneration projects that have adopted extensive stone cleaning (Milligan in Webster, 1992; Simpson in Webster, 1992). Patina finds direct parallel in the Eastern philosophy of Wabi Sabi, which celebrates imperfection and aging that transcend the physical form. Not only this, but in an architectural heritage context, many old parts of buildings are integrated and retained (e.g. Yokohama and in the case of Ueno Park) when areas are rebuilt after destruction from, for example, seismic activity. Respect for aging and evidence of the 'golden stain of time' are therefore widely accepted. Patina, in a Western context, arguably has a higher degree of cultural superficiality than the Eastern construct of Wabi Sabi, which has a much stronger philosophical and cultural underpinning. Yet, in Western heritage sectors outside the built environment such as classic sculpture and antiques, it is considered a hallmark of authenticity.

In addition, a further comparison is that Kiku Kiwari helps support the notion of pattern book restoration via the reproduction of process and reduction of conjecture. Taking the adoption of pattern books in support of permanence to its logical conclusion leads to the 'Ship of Theseus' paradox that is ultimately difficult to reconcile. The adoption of pattern books with reduced levels of conjecture enable the reproduction of building components and elements. Importantly, Ruskin (1849) suggests that a building has 'memory' through cumulative physical change and development of its storytelling narrative, here we argue that also the building 'process', most notably associated with Kiku Kiwari, similarly possess memory imbued with cultural meaning. Significantly, the Nara document notes the "essential contribution made by the consideration of authenticity in conservation practice is to clarify and illuminate the collective memory of humanity" (Nara, 1993, cf. Reynolds, 2015) and is essential in the relationship between architecture and humanity (Suzuki, 2018). Today, contemporary pattern books have been largely replaced by advances in digital reality capture technologies such as laser scanning and photogrammetry, which have increasing point cloud density and completeness of data that effectively obviates conjecture of external surface form. Nevertheless, whilst the documentary robustness that forms the basis of repair strategies has increased, faithful reproduction is arguably less philosophically defensible as we move towards the perfect realisation of the 'Ship of Theseus' paradox as advancing, digital reality capture and 3D printing production methods will enable the identical replacement of increasingly complex architectural components. Advances in printing technologies create a counterpart insomuch as we can gather an almost perfect record of what exists, and can digitally print replicating form. Indeed, it could be argued that this tension between original and facsimile will become more difficult to reconcile as innovation in printing materials occurs (i.e. printing stone substitutes etc.), making facsimile fabric replacement compositionally, textually, and in terms of external surface form, indistinguishable from the original. We can reproduce the 
surfaces alluded to by Ruskin as being 'impossible to recreate', opening up this new dilemma of authenticity in conservation but on a different order of magnitude. In addition, advancing digital technologies also have significant implications for the continuity of craft skills and Intangible Cultural Heritage with the 'memory of process' being lost.

The primary tenet of 'minimum intervention' is essential for the retention of the maximum amount of historic fabric and is the cornerstone of conservative repair strategies. More recently, minimal intervention strategies have been harnessed in making a positive contribution in maintenance for historic buildings facilitating 'green maintenance' operations and retaining embodied energy 'locked up' in fabric (Forster et al., 2011). Conversely, restorative approaches (and Kiku Kiwari) with their greater acceptance of wider fabric intervention, replacement and rebuild, create the conditions for unnecessary and increasing expenditure in carbon associated with fabric repair and adaptation. Therefore, Restoration may find support for the attainment of a unified building aesthetic, and continuation of craft skills, but may struggle to substantiate interventions beyond a minimum within a decarbonising built environment. It seems untenable to substantiate reconstruction akin to that seen in Kiku Kiwari (temple rebuild) given the unnecessary utilisation of virgin material and the associated energy for 'cradle to site' (Hammond \& Jones, 2008) procurement and construction of new buildings. It must however be qualified that temple reconstruction and repair, is only undertaken when absolutely necessary (Ito, 2002) and only on a large scale in exceptional cases, often for the religious deities of specific temples, as in the case of the Ise shrine (Akagawa, 2014). What is more, an unintended consequence of the need to decarbonise construction could be that it inadvertently generates greater acceptance of honesty in repair and minimal intervention strategies, within an environmental mantra of fabric oriented 'make do and mend', minimising the environmental damage by ongoing extraction of virgin resources.

It seems understandable to attempt to strive for longevity and permanence in architectural form, as structures and their meaning are integral to our cultural identity. However, this aspiration is ultimately unrealistic given the nature of entropy in building fabric decay. It would be logical to focus efforts upon strategies that best attain longevity and therefore maximise permanence. Indeed, reversible, well considered honest repairs that are utilised as part of broader minimum intervention approach should enhance fabric retention and should be sought. It should however be emphasised that conservative repair and restoration strategies are not binary and it would be prudent for both factions to better understand the benefits and deficiencies of their philosophical positions as they seek approaches that recognise either permanence or impermanence. Indeed, visible repair in Japan culturally reminds the individual observer of impermanence in the repaired artefact and in life itself. This view, whilst not commonly associated with the interpretation of architectural change in the West, may be an opportunity for an individual to learn from the East and reflect upon the overt messages and philosophical signals that are imbued and transcend the built form being observed. 
Importantly, it is arguable that an element that differentiates East from West is that in practice the West has a conscious bias to the tangible and by virtue an absence of focus on the intangible. It is clearly easier for the West to focus on form and fabric that they are inherently more comfortable with than spiritual, which is clearly in the "intangible heritage realm" (Akagawa, 2014, p.72). Key to this focus are considerations of climate, language, but also the role of intangible cultural heritage in machizukuri (townmaking) and furusato (homemaking) (Akagawa, 2014) and the personification of buildings such as Himeji Castle (Utaka, 2013).

In addition, philosophies of repair and their influence upon design intervention are arguably largely alien to the western layperson but they are extensively interrogated and implemented by building conservation practitioners. Indeed, without professional guidance tempering restorative interventions, the design default may be to simply reproduce schemes that ultimately confuse and dilute the historic record, potentially, stymying architectural innovation within an historic built environment context.

We argue that the above exploration outlined here raises a number of questions related to building conservation and philosophical approaches and represent significant opportunities for further investigation. Specifically, why has Kintsugi not permeated architectural practice and building repair in a Japanese context? Further, why is the concept of obtrusive repair unable to find greater acceptance or architectural traction in mainland Europe given that legible intervention can be seen through a lens of aesthetic beauty contributing to a historic story telling narrative? Also, do advancing technologies, by removing the creator from the process, remove much of the sense of achievement and creativity involved?

Finally, we assert that there are indeed underlying universal philosophies and ideas related to permanence in both Eastern and Western approaches, but their overt recognition, decoding and meaning requires greater analysis. We recognise that in this assertion we may be ourselves coming from a Western perspective of interpretation, but feel that through the process of researching and writing this paper in itself has brought us closer to understanding Eastern approaches and principles to conservation.

Ultimately, understanding can only be achieved by increased dialogue between cultures, within an environment that facilitates respect for values held in diverse parts of the world. A recognition that both Eastern and Western cultures value their historic buildings and appreciate the importance they play in their contribution to their national identity and 'collective societal memory' should not be forgotten. Indeed, omni-present collective inheritance in these cultures can be considered as the 'origin' or 'root' for the motivation to conserve. This shared appreciation should be a starting point for balanced dialogue pertaining commonality of both tangible and intangible heritage and the appropriate, culturally contextualised, philosophically derived treatments required for contemporary building conservation. 


\section{References}

Ackerman, J S., (1966). 'Palladio'. Penguin Books, Harmondsworth

Akagawa, N. 2014. Heritage conservation and Japan's cultural diplomacy: Heritage, national identity and national interest, Vol. 53. Routledge. London.

Alberti, L.B., (1966). 'Ten Books on Architecture', ed. J. Rykwert. New York. Transatlantic Arts. [Original 1485]

Avrami, E., Mason, R. and De La Torre, M. (2000), Values and Heritage Conservation, The Getty Institute Trust, Los Angeles,

CA

Bell, D (1997) 'Technical Advice Note 8: The Historic Scotland Guide to International Charters' HMSO, Edinburgh

Blair, D. (2006) Wittgenstein, Language and Information: 'Back to the Rough Ground!' The Netherlands: Springer.

Brereton, C. (1995). 'The Repair of Historic Buildings-Advice on Principles and Methods', London: English Heritage.

Brooks, M. W. (1989). John Ruskin and Victorian architecture. London: Thames and Hudson.

Burman, P (1995). 'A Question of Ethics' Available at:

http://www.buildingconservation.com/articles/ethics/conservation ethics.htm last accessed November 2017

BS7913, (2013). 'The principles of the conservation of historic buildings' BSi, Tunbridge Wells, UK [original version 1998]

Cecchi, R. and Gasparoli, P., (2012). 'Preventive and planned maintenance of protected buildings: methodological tools for the development of inspection activities and maintenance plans'. Alinea. Firenze, Italy

De Botton, A., (2006). 'The architecture of happiness'. Vintage. New York

Earl, J (2006) 'Building Conservation Philosophy' $3^{\text {rd }}$ Ed, Donhead, Somerset

Forster, A. M., \& Kayan, B. (2009). Maintenance for historic buildings: a current perspective. Structural Survey, 27(3), 210229.

Forster A.M, (2010a) Building conservation philosophy for masonry repair: Part 1 'Ethics' Structural Survey: Journal of Building Pathology \& Refurbishment 28(2), 91-107

Forster A.M, (2010b) 'Building conservation philosophy for masonry repair: Part 2 'Principles' Structural Survey: Journal of Building Pathology \& Refurbishment 28(3), 165-188

Forster A.M., (2010c) Masonry repair options and their philosophical ramifications. Proceedings of the International RILEM workshop (PRO), Historic Mortars: Characteristics and tests, 2010, Prague Pp. 973-982

Forster A.M, and Douglas, J.E. (2010) Condition survey objectivity \& philosophy driven masonry repair: An increased probability for project divergence? Structural Survey: Journal of Building Pathology \& Refurbishment 28(5), 384-407

Forster A.M, Carter, K, Banfill, P.F.G, and Kayan B, (2011) Green Maintenance for historic masonry buildings: an emerging concept. Building Research and Information 39(6), 656-664

Feilden, B. M. (2003). Conservation of Historic Buildings. Routledge, Oxford, UK.

Gopnik, Blake. (2009). “At Freer, Aesthetic Is Simply Smashing.” The Washington Post. March 3.

Guardian (2016) Palmyra's Arch of Triumph recreated in Trafalgar Square. Available at:

https://www.theguardian.com/culture/2016/apr/19/palmyras-triumphal-arch-recreated-in-trafalgar-square Last Accessed January 2018

Guthrie, W. K. C. (1977). A history of Greek philosophy: Volume I. Cambridge: Cambridge University press.

Hammond, G.P. and Jones, C.I. (2008), Embodied energy and carbon in construction materials. Proceedings of the Institution Civil Engineers, Energy, 161, Issue EN2, pp. 87-98.

Hartman, R.S. (1967) The Structure of Value: Foundations of Scientific Axiology. Southern Illinois University Press, Feffer and Simons Inc. Carbondale, IL, USA.

Hill, P (1995) 'Conservation and the stonemason', Journal of Architectural Conservation, Vol: 1 Part 2, pp. 7-20

Hobbes, T (1999). 'De Corpore 2.11'. Oxford: World's Classics. [Original published 1655.] 
Holman, D., and Vertegaal, R. (2008). Organic user interfaces: designing computers in any way, shape, or form. 'Communications of the ACM', 51(6), 48-55.

Honderich, T. (1995). 'The Oxford Companion to Philosophy'. Oxford: Oxford University Press.

lamandi, C. (1997). The Charters of Athens of 1931 and 1933: Coincidence, controversy and convergence. Conservation and management of Archaeological sites, 2(1), 17-28.

ICOMOS (1983) 'International Council on Monuments and Sites'; ICOMOS Canada. English-speaking Committee. The Appleton Charter for the Protection and Enhancement of the Built Environment. Available at: http://www.icomos.org/charters/appleton.pdf last accessed November 2017

Ito, N, (1995) "Authenticity" inherent in cultural heritage in Asia and Japan' in KE Larsen (Ed) Nara conference on authenticity in Relation to the World Heritage Convention, Nara, Japan, 1-6 November, 1994, Proceedings, UNESCO World Heritage Centre, Paris, pp $35-45$

Ito, N (2002) 'World cultural Heritage and self-enlightenment of conservation exerts' in Report of the consultative meeting on the regional cooperation in cultural heritage protection in Asia and the Pacific 29 February - 3 March 2000,

Asia/Pacific Cultural Centre for UNESCO (ACCU) Nara, Japan, pp15-17, ICOMOS

Ito, N. (2003). 'Intangible cultural heritage involved in tangible cultural heritage'. Available at http://openarchive.icomos.org/484/ last Accessed November 2017

Jiang, Q., Feng, X., Gong, Y., Song, L., Ran, S., \& Cui, J. (2016). Reverse modelling of natural rock joints using 3D scanning and 3D printing. Computers and Geotechnics, 73, 210-220.

JAANUS (n.d.) 'Kiku. Japanese Architecture and Art Net Users System'. http://www.aisf.or.jp/ jaanus/ Last accessed: September 2017

Jokilehto, J. (1998). The context of the Venice Charter (1964). 'Conservation and management of archaeological sites', 2(4), 229-233.

Jokilehto, J. (2007). 'History of architectural conservation'. Routledge. London.

Juniper, A. (2011). 'Wabi sabi: The Japanese art of impermanence'. Tuttle Publishing. Rutland, USA

Keene, D. (1972) 'Landscapes and Portraits: Appreciations of Japanese Culture' London: Secker and Warburg.

Keulemans, G. (2016). The Geo-cultural Conditions of Kintsugi. The Journal of Modern Craft, 9(1), 15-34.

Koren, L (1994) 'Wabi Sabi: for artists, designers, poets \& philosophers'. USA: Stone Bridge Press

Kuroda, T (2016) Yokohama: Regeneration and Requalification of the Historical Urban Tissue of the Old Port City. In Niglio, O. (Ed.). (2016). Historic Towns between East and West. Aracne editrice. Pp 329 - 337.

Kuroishi, I., (2015). Mathematics of Carpentry in Historic Japanese Architecture. In K. Williams \& M. J. Ostwald, eds. 'Architecture and Mathematics from Antiquity to the Future: Volume 1: Antiquity to the 1500s'. Heidelberg: Springer, pp. 333-348.

Kwan, P. Y. (2012). 'Exploring Japanese Art and Aesthetic as Inspiration for Emotionally Durable Design'. DesignEd Asia. Hong Kong.

Larkosh, C. (2014). 'Minor' Languages, 'Broken' Translations: On Brazilian Reworkings of an Albanian Novel. International Journal of Society, Culture \& Language, 2(2), 68.

Larsen, K.E. (Ed) (1994) Nara conference on authenticity in Relation to the World Heritage Convention, Nara, Japan, 1-6 November, 1994, Proceedings, UNESCO World Heritage Centre, Paris.

Logan, W. (2004). Voices from the periphery: The Burra Charter in context. Historic Environment, 18(1), 2.

Makowski, P. T. (2016). Intention inertia and the plasticity of planning. Philosophical Psychology, 29(7), 1045-1056.

Milligan, A 'To clean or not to clean buildings within Edinburgh' in - Webster, R (1992) 'Stone cleaning and the nature, soiling and decay mechanisms of stone' Donhead, London 
Morris, W. (1877). Manifesto of the Society for the Protection of Ancient Buildings. Historical and Philosophical Issues in the Conservation of Cultural Heritage, 319-321.

Munoz-Vinas, S. (2012). Contemporary Theory of Conservation. Routledge. London

Nara (1993) The Nara Document on Authenticity. ICOMOS: Nara, Japan.

Niglio, O. (2012). The silk: A subtle thread that, for centuries, has brought together the peoples of East and West. Apuntes: Revista de Estudios sobre Patrimonio Cultural-Journal of Cultural Heritage Studies, 25(1), 82-89.

Niglio, O. (2014). Inheritance and identity of Cultural Heritage. Advances in Literary Study, 2(1), 1-4.

Nishimura, Y (2008) Renovation of Modern Stock. In Fujino, Y., \& Noguchi, T. (Eds.). (2008). Stock Management for Sustainable Urban Regeneration (Vol. 4). Springer Science \& Business Media. Pp 33 - 56. Tokyo.

Okakura, K (1906) 'The Book of Tea', Penguin Books, London.Paine, R. T., \& Soper, A. C. (1960). The art and architecture of Japan. Harmondsworth, Middlesex: Penguin Books.

Palladio, A. (1965). Palladio, Andrea, 1508-1580 the four books of architecture. New York: Dover.

Park, T. L. (2013). Process of architectural wooden preservation in Japan. WIT Transactions on The Built Environment, 131, 491-502.

Plutarch (1864) The Lives of the Noble Grecians and Romans. Modern Library, NY (reprint of the edition published in 1864). Translated by J. Dryden and revised by A.H.Clough.

Powys, A.R (1995) 'Repair of Ancient Buildings' Society for the Protection of Ancient Buildings. London

Reynolds, J. M. (2001). Maekawa Kunio and the emergence of Japanese modernist architecture. Univ of California Press. Berkeley.

Reynolds, J. M. (2015). Allegories of Time and Space: Japanese Identity in Photography and Architecture. University of Hawai'i Press. Honolulu.

Richards, K., \& Pilcher, N. (2014). Contextualising higher education assessment task words with an 'anti-glossary' approach. International Journal of Qualitative Studies in Education, 27(5), 604-625.

Richards, K., \& Pilcher, N. (2018). Academic literacies: the word is not enough. Teaching in Higher Education, 23(2), 162-177. Richie, D. (2007). 'A Tractate on Japanese Aesthetics'. Berkeley, CA: Stone Bridge Press.

Rodrigues DJ, and Grossi A (2007): Indicators and ratings for the compatibility assessment of conservation actions. J Cult Heritage, 8:32-43.

Ruskin (1849) 'The Seven Lamps of Architecture'. Smith, Elder \& Co. London. UK

Ruskin, J (1851) 'The stones of Venice. Volume the First. The Foundations'. Smith, Elder and Company, London, UK

Ruskin, J., (1853). 'The stones of Venice. Volume the third. The fall.' Smith, Elder and Company, London, UK

Sachs, J. (2005). Aristotle: Motion and its Place in Nature. The Internet Encyclopaedia of Philosophy, ISSN: 2161-0002, http://www.iep.utm.edu/, 15 December 2017.

Scaltsas, T. (1980). The ship of Theseus. Analysis, 40(3), 152-157.

Simpson, J 'Stone cleaning - a professional view' in - Webster, R (1992) 'Stone cleaning and the nature, soiling and decay mechanisms of stone' Donhead, London

SPAB (1877) 'Manifesto' Available at: http://www.spab.org.uk/what-is-spab/the-manifesto/ Last Accessed September 2009 Starling, S. (2008). Five thousand years (some notes, some works). The Journal of Modern Craft, 1(1), 117-131.

Stovel, H (1995) Consideration in framing the authenticity question for conservation in KE Larsen (Ed) Nara conference on authenticity in Relation to the World Heritage Convention, Nara, Japan, 1-6 November, 1994, Proceedings, UNESCO World Heritage Centre, Paris, pp 393-398. ICOMOS.

Stratton, A., (1932). 'The Orders of Architecture: Greek, Roman, and Renaissance.' Available at:

http://afe.easia.columbia.edu/main pop/kpct/kp tokugawa.htm Last Accessed April, 2016 
Suebsuk, N., and Nakagawa, O. (No date) 'Transformation and Modification of Historical Building Use, and Owner Motivation for Urban Conservation in the Nineizaka and Sanneizaka Preservation District', Kyoto, Japan.Suzuki, R (2018) Cerebral Garden \#5 Available at http://www.artligue.fr/en/artwork/1178/ryo-suzuki-cerebral-garden--5 Accessed may 2018.

Takagi, H. (2012). Fabricating Antiquity in Modern Nara. Translated by John Breen and Regan Murphy

Torney, C., Forster, A. M., Kennedy, C. J., \& Hyslop, E. K. (2012). “Plastic” repair of natural stone in Scotland: perceptions and practice. Structural Survey, 30(4), 297-311.

Torney, C, Forster, A.M, Szadurski, E (2014) Specialist 'restoration mortars': A comparison of the physical properties of two stone repair materials Heritage Science 2(1)

Treviranus, J. (2010). The value of imperfection: the Wabi Sabi principle in aesthetics and learning. 2010 Proceedings. Barcelona: UOC, OU, BYU.[Accessed: dd/mm/yy].<http://hdl. handle. net/10609/4869.

UNESCO (2017) 'Traditional Craftsmanshi'p. Available at http://www.unesco.org/culture/ich/en/traditional-craftsmanship00057 Last Accessed November 2017Utaka, Y (2013) The Himeji Castle world heritage site: challenges of sustaining memories of a revered heritage in Japan. In Silva, K. D., \& Chapagain, N. K. (Eds.). Asian heritage management: Contexts, concerns, and prospects. London: Routledge.

V\&A (2017) 'Style Guide: Influence of Japan'. Available at: http://www.vam.ac.uk/content/articles/s/style-guide-influenceof-japan/ last Accessed March 272017

Vitruvius (1914) The Ten Books on Architecture, translated by Morris Hicky Morgan. London: Oxford University Press [original no date; circa 30 - $15 \mathrm{BC}]$

Warland, E. G. (1984) "Modern Practical Masonry" reprinted by the Stone Federation, 1984, first published 1929.

Watkin, D. (2015), 'The Practice of Classical Architecture: The Architecture of Quinlan and Francis Terry, 2005 - 2015' Rizzoli, US.

Watt, D. S. (2009). 'Building pathology: Principles and practice'. John Wiley \& Sons.

Webster, R (1992) 'Stone cleaning and the nature, soiling and decay mechanisms of stone' Donhead, London

Weintraub, S, Walters, S.Y and Tsujimoto, K. (1979). “Urushi and Conservation: The Use of Japanese Lacquer in the Restoration of Japanese Art." Ars Orientalis 11: 39-62.

Yamato, S (2006) 'The Tradition of Wooden Architecture in Japan'. Agency for Cultural Affairs. Tokyo, Japan 